\title{
Trafficking Twin Terror: Mysterious Madam and Voodoo Victimisation in the Case of Nigeria
}

\author{
Usman Mika'il Usman \\ PhD Candidate at the Department of Development Studies, \\ Faculty of Economics and Administration, \\ University of Malaya, 50603 Kuala Lumpur, Malaysia \\ E-mail: umu9933@gmail.com \\ Assoc. Prof. Dr. Raja Noriza Raja Ariffin \\ Department of Administrative Studies and Politics, \\ Faculty of Economics and Administration, \\ University of Malaya, Kuala Lumpur, Malaysia \\ E-mail: rnoriza@um.edu.my \\ Senior Lecturer, Dr. Azmah Binti Haji Othman \\ "Corresponding Author": Department of Development Studies, \\ Faculty of Economics and Administration, \\ University of Malaya, Kuala Lumpur, Malaysia \\ E-mail: g3azmah@um.edu.my
}

Received: Mar. 12, 2018 Accepted: Mar. 30, 2018 Online published: Apr. 8, 2018

doi:10.5296/jpag.v8i1.12765

URL: https://doi.org/10.5296/jpag.v8i1.12765

\begin{abstract}
The trafficking in human beings has turned out to be a menace that is difficult to eliminate, in spite of the significant policies, organisations, protective, preventable and prosecutable measures in place. Nevertheless, mysterious madam and voodoo victimisation are trafficking twin terror and two critical exploitative phenomena that had persisted and sustained
\end{abstract}


international prostitution. There is little scholarly research which contributed to the said research area. This research utilises a multiple of qualitative research method of semi-structured one on one interviews, written documents, and observations with participants from government officials, nongovernmental organisation representatives and academics who are individuals indirectly or directly involved in trafficking for international prostitution in Nigeria. The study calls on the federal government to commit the village, ward, district heads, community and religious leaders in their respective communities actively.

Keywords: trafficking twin terror, Madam, Voodoo, international prostitution, Nigeria

\section{Introduction}

The magnitude and severity of modern-day slavery have tremendously increased, and it remains a challenge to governments (Agbu, 2003; Adepoju, 2005; Olubukola, 2014). The International Organisation for Migration (IOM), in the year 2015 has approximated that 244 million individuals around the globe were illegal immigrants, an unprecedented and highest number of international migrants. In this way, women are the most receiving end and ended up in prostitution and the most massive migrants to Europe. In the year 2014, the most significant number of immigrants of about 170,000 arrived in Italy alone by sea. The majority of the migrants were from Eritrea with 39,162 followed by Nigeria 22,237 and Somalia 12,433 being the worst three countries amongst African and other countries (International Organization for Migration, 2016), mostly, these illegal migrants are women, and the majority end up in the sex industry.

Then again, the Nigerian trafficked victims for sexual exploitation is amongst the most noticeable and increasing of any nation in Africa (Laczko, 2005; National Agency for the Protection of Trafficking in Persons, 2016). Human trafficking is a pressing social issue whose empirical research merits careful investigation. Nevertheless, Nigeria is the leading country in Africa to ratify and accede to the human trafficking convention, and she domesticated the protocol by inaugurating the national agency for the protection of trafficking in persons and other related matters in the year 2003, popularly known as (NAPTIP). The agency was the first of its kind in the continent, mandated to protect, prevent, investigate and prosecute traffickers. In this direction, a lot of successes have been recorded, from the inception so far 10,815 victims have been rescued, 3,415 cases investigated and a meager 315 convicted persons. Consequently, despite the remarkable progress, the data shows there have been limited arrest and prosecution of traffickers (madams) and voodoo ritualists about the scale and size of the menace (Naptip, 2017). Thus, this is due to the passive role played by the crucial stakeholders to fight traffickers in the communities and the primary source level; this is the knowledge gap the study is going to fill. But then, every year, thousands of Nigerian women are being trafficked to western European countries, and more than 90 percent engage in prostitution (Agbu, 2003; Etchingham, 2015). Furthermore, at a point when Nigerian immigrants are sheltered in European asylum camp, the police regularly find it difficult to quiz women as result of mysterious voodoo oath that keeps the victim silent and away from saying their experiences (Kamerman \& Wittenberg, 2009). Also, desperate economic conditions amongst several vulnerable victims, pictures of a decent future in 
Europe remains a favourite thing for an average Nigerian (Adepoju, 2005). Thus, these situations persisted with Nigerian victims under the control of human traffickers, in particular, the madam with the tight connection of voodoo priest. Consequently, literature review acknowledged the existence of voodoo and madam as a bane to human trafficking phenomenon, as well as how voodoo oath served as a control measure against vulnerable victims. Nonetheless, literature is missing on why voodoo and madam combined are the twin terror to the persistence of international prostitution in women and girls from empirical evidence.

Furthermore, the issue with the idea of this psychological and physical control exacerbated by the madam and the voodoo priest is that it delays the prevention, prosecution, and protection of trafficking. In this manner, this research articulates a shortage of empirical literature specifically on the voodoo usage that centred around madam. Also, as the trafficking twin terror by exacerbating international prostitution ring which is clandestine, that can be decreased and remedied if measures, as proposed by the study, are implemented. The next part discusses the literature review, followed by the methodology, then the study describes the findings and discussion, and finally, the research concludes with recommendations.

\section{Literature Review}

\subsection{Madam and Voodoo}

Madams are females from Africa and are primarily the traffickers especially Nigerians and Ghanaians. In similar research conducted in Italy, the study founds principal traffickers to western Europe to be women; the finding shows women as the pioneers of international prostitution (Monzini, 2005). In consequence, the madam designs the activities and lead the clandestine network that is usually small in number but operates internationally (Mancuso, 2014). She manages victims of the prostitution, the madam coordinates the recruitment of victims and at the communities where her subordinates work day by day recruiting victims. The madam also connived with corrupt officials who not only provide passage for the recruited victims but arranged stolen or false passport and do make available, other necessary travel documents (Carling, 2005).

However, voodoo can be illustrated as a charm or fetish that is accepted though not constrained to West African nations to have supernatural or magical powers (Bell, 2011) for the most part revengeful. Accordingly, Oviasuyi, Ajagun \& Lawrence defined voodoo oath as a "situation where absolute loyalty or adherence to certain agreement and conditionality is prescribed and administered [to] the beneficiaries of the agreement, and the exercise is usually fetish" (2011:194). Nevertheless, Jenny is of the opinion that prejudice is connected to investigating the issue of voodoo, as a negative picture of the African people's culture. The expression of the term as black magic is equivalent to asserting negative qualities and generalisation onto magic. Therefore, these signify pessimism which can be connected with the developed nations assertion and obscurity of black people, proportionate to a vast degree that represent Africans (2011). On the other hand, Weitzer's finding started at the micro level, the benefit, and improvement in knowing the magnitude of the human trafficking problem. There are substantially documented records of the involved trafficking experiences and 
well-formulated policy and enforcement measures. He listed immigration obstacles in destination countries, the money spent on transit states and focuses on traffickers as they engage in coercion, deception, and exploitation of trafficked women. The article enumerated the role of small networks or a single individual that may also involve relatives, acquaintances, and friends. According to Weitzer, the more immigration laws at border become stringent, the higher the chances of women will be in the hands of traffickers (Weitzer, 2015). Furthermore, in the words of Paolo trafficking network do not run along family lines, instead, operate either on ethnic affiliation or as independent agents that serve as contractors. The networks are distinct in their areas of specialisation and well defined and assigned responsibility based on competencies. The author argues for a more in-depth look at the monetary aspect of the trafficking phenomenon to understand organisational structures employed by criminal networks (Paolo, 2015).

According to Fiona trafficking is growing nationally and internationally with an increase in information about criminal networks, their connections, methods of operation and the magnitude of their organisations. The author points to a knowledge gap in the study of criminal organisations, stating, there is little scholarly research which contributed to the under-researched area. The study reveals a network of criminality as an emerging phenomenon in trafficking that is multifaceted and complicated. The article found a relatively diversified form of operation and some sophisticated characteristics regarding size, structure, and method of trafficking operation by traffickers (Fiona, 2012).

Arsovska significant finding is on insufficient information regarding the role played by women in organised crime internationally; as said, there is a lack of data to this end. Women continue to be subjugated. Hence, the international organised crime of trafficking in women is a mere continuation of other areas of inequity to the women's life. The article found a Balkan network of criminals engaged in drugs, arms and human trafficking. The study sees fraud, extortion, organised theft and money laundering using Balkan women and where there is possible resistance, extreme violence is exercise. On the West African organised network, human trafficking for prostitution has been increasing for the reason of insufficient economic and social opportunities. Women being the active group leaders acting as madams, organisers, traffickers, recruiters and exploiters. The author traced African women history where they have had power and privilege independently translated and capable of leading criminal organisations. The literature found Balkan women are not active but passive, there trafficking is to assist loved ones and family members if need be, just helping their men or a sort of support to the family (Arsovska, 2013).

\subsection{Trafficking Twin Terror}

The trafficking twin terror is the unusual but paired by similar, deliberate, serious injury that involves extreme fear, threat, violence, madness and death (Toyin \& Niyi, 2007) to the vulnerable victims caused by the madam and voodoo priest. It is also, a partnership that is mutually beneficial, closely correlated in the physical and psychological control and strongly interconnected actions in the shrine by the madams and the voodoo priests that ignite and incite intense fear, intimidation and threat to the vulnerable women as victims of international 
prostitution. However, Nigeria national agency for the prohibition of trafficking in persons and other related matters (Naptip) is saddled with the responsibility to trace, track and deal with traffickers especially the madams and the voodoo priests to curtail all trafficking activities and prosecute them as enshrined by the Naptip act of 2003 as amended. To this end, the agency is fighting to salvage the plight of the victims. Thus, a lot needs to be done vis-a-vis trafficking twin terror, as depicted in table 1 to be discussed in the subsequent section.

\section{Methodology}

The problematic and widespread nature of the international prostitution research carried out a call for an investigation on trafficking in women data to be triangulated. This research utilises a multiple of qualitative research method of semi-structured one on one interviews, written documents and observations to demonstrate international prostitution in Nigeria. The utilisation of combined methods of the collected data enabled triangulation to attain reliability and validity (Golafshani, 2003). Hence, the interviews were semi-structured conducted with participants from government officials, non-governmental organisations representatives and academics who are individuals indirectly or directly involved in trafficking for international prostitution endeavours'. This study has contributed to understanding better and having reach information on human trafficking international prostitution dimension by the interviewing persons at their place of work that led to detail been established. Thus, the research questions this investigation seeks answers are; How do voodoo and Madam Influence the persistence of international Prostitution in Nigeria? And Why does madam play the dominant position in international Prostitution?

\section{Findings and Discussion}

The difficulty surrounding trafficking for international prostitution are numerous; nevertheless, mysterious madam and voodoo victimisation as trafficking twin terror are two critical exploitative phenomena that had persisted and sustained the menace, this can be evidently determined from the following analysis

\subsection{Mysterious Madam}

The Nigerian prostitution ring discovered the possibility to invest and run international prostitution abroad in various ways and at multiple levels. In a similar but different way interviewee commented:

Mostly they are a syndicate, too sophisticated, challenging to track them in the sense that they try to think ahead and modify their mode of operations.

Hence, madams are mostly in their 30's of years and above signifying experienced in prostitution and found that they could make money if they continue to recruit and service the demand for African women in western Europe. A lot of the madams from Nigeria after spending years in the prostitution business discovered that sourcing victims and coercing or selling them could earn them money. Meaning they have found a lucrative trade that is easy to do, less risky with voodoo to aid, abate and control trafficked women (Monzini, 2005; Seo, 
Axel \& Eric, 2013). In the same vein, slightly differing in view is an interviewee looking deep down into activities at the rural areas, and asserted madams as:

They use to recruit locally, and they have their agents in Europe where they will take girls there.

The madam dictates, order the victims into exploitative forced prostitution and collect the money herself. Madam controls and instruct victims arranged their clothes and gave conditions. The long-term madams experience made clients to put trust in her, she knows all about prostitution, presents herself well dressed up, and the way she spoke authoritatively signifies regular and ongoing criminal woman leader. The madam works with male associates as Carling called them 'black boys' of madams (2005). According to Van \& Gijsbert, the madam's black boys play the role of messengers, guides, money couriers, debt collectors and recruiters (2004). They are amongst Nigerians forced into prostitution, gained independent and joined exploitative industry and became offenders or well known as madam boys (Evelyn \& Chukwuka, 2017). Madams perform a significant task, the like of establishing contact with victims' families and with a fellow network of clandestine criminals. In fact, severally they play a key role as leaders especially Nigerian women in the prostitution ring (Kleemans, 2007). Madams are women offenders, traffickers and exploiters who play a lead and central role that coordinate and facilitate prostitution activities of the criminal network. Consequently, madam and the associate have been reported by the United Nations Educational, Scientific and Cultural Organization (UNESCO) as:

"Nigerian traffickers abroad have established mafia-like organisations of control in most destination countries. They are well-connected and operate in cartels and networks which are difficult and risky to infiltrate. They are ruthless and will sacrifice anyone to cover their tracks and remain hidden. They use codes for communication among themselves. Traffickers do not always operate in groups, however, and some engage in solo operations." (UNESCO, 2018)

In this way, at every stage madam forge partnership either with boyfriend, husband or criminals in same trafficking activity. The task of such partnership differs, it could be a division of labour, or when it comes to threat or violence and transporting victims, the madam's bad boys are more capable. while regarding recruitment of victims, voodoo victimisation at the shrine, and exploitation, the madams are the organisers in the prostitution industry. As a result, the human trafficking happening revolve and employed by the madam can be seen by the unfortunate economic situation in which women find themselves on one side, and the smooth, quick money making on the other, that necessitate traffickers to look for greener pasture in Europe.

\subsection{Madam, Victim and the Voodoo Priest}

The young women are taken to the shrine, to meet a juju priest who is usually in a detached place. The shrine is mostly located in a forest or bush, and even those that live within communities or among other individuals utilise a room that is mainly committed as a particular shrine (Mojeed, 2008). The condition of the shrine alone is sufficient to make 
anyone fearful. Empirical information demonstrates that while voodoo is being utilised as a part of the measures to secure and control victims of trafficking, it is mostly the utilisation of voodoo taking that is overwhelmingly alarming. Both voodoo rituals and juju fetish are frequently utilised as a control system to keep women from trafficking in prostitution and vulnerable to the madams. Voodoo oath is part of or as an important attribute of the victim's recruitment process in human trafficking and as a so-called agreement between trafficker and the victim who is subjugated to dubious activities that include numerous acts at the shrine for rituals both at home and abroad (May, 2017). Nevertheless, Naptip, as mandated by the government through its policy, is fighting traffickers and this is corroborated by an interviewee:

The government is trying, the set-up of the agency is okay, departments are okay, and the agency underwent several reorganisation and restructuring which I believe is done in good faith, particularly to confront the daunting task of the traffickers.

Similarly, on a separate point an interviewee mentioned using authoritative powers vested in the agency and asked the voodoo priest to revoke the oath, as cited:

I have passed a case that pubic hair has been cut as part of the body deposited in the shrine and I recovered it. The shrine man has to give evidence at the court, so when I use myself as an example they (victims)opened up, they tell me their story and the priest has to go to the court.

Thus, this is a welcome development by the government official interviewed, using experience, knowledge, and expertise to calm victims, a unique and exceptional remedy but far from the actual or real solution. On the contrary, in fact recently the Director General (DG) of the Naptip asserted to ally with the so-called witch doctor as another name to the voodoo priest, she was quoted to have said:

"we gathered these witch doctors recently... in the city engaged their services and made them ambassadors in fighting the menace." (Vanguard, 2018)

Therefore, this is a sign of the disconnect between the middle level and the top level Naptip staff. That is while the middle level at the scene of action, as stated in this study, see the activities of the shrine priest as evil. Even to the extent of going to the shrine to make sure the voodoo has been revoked, the senior and the top level management that sits in the office, virtually know little of the actual activities of madams and shrine on the ground thinks the voodoo priests are part of the solution. No wonder the DG did not talk about the role of madam as a partner to the priest, neither the victim's body parts deposited along with fetish used at the shrine. But merely call on the juju priests to be part of the fight despite all the atrocities they have committed in connivance with madams that usually take victims to the shrine. Hence the juju controls all aspect of victim's life, and nothing is said to be hidden for the oath (Jenny, 2011; Etchingham, 2015). This combined effect (madam and voodoo) is also another new dimension to the trafficking menace, as a consequence, the table below conceptualise and depict the actual twin trafficking terror. Thus, figure 1 indicates a critical exploitative relationship between madam and voodoo priest and the trends of trafficking 


\section{Macrothink}

victim's situation.

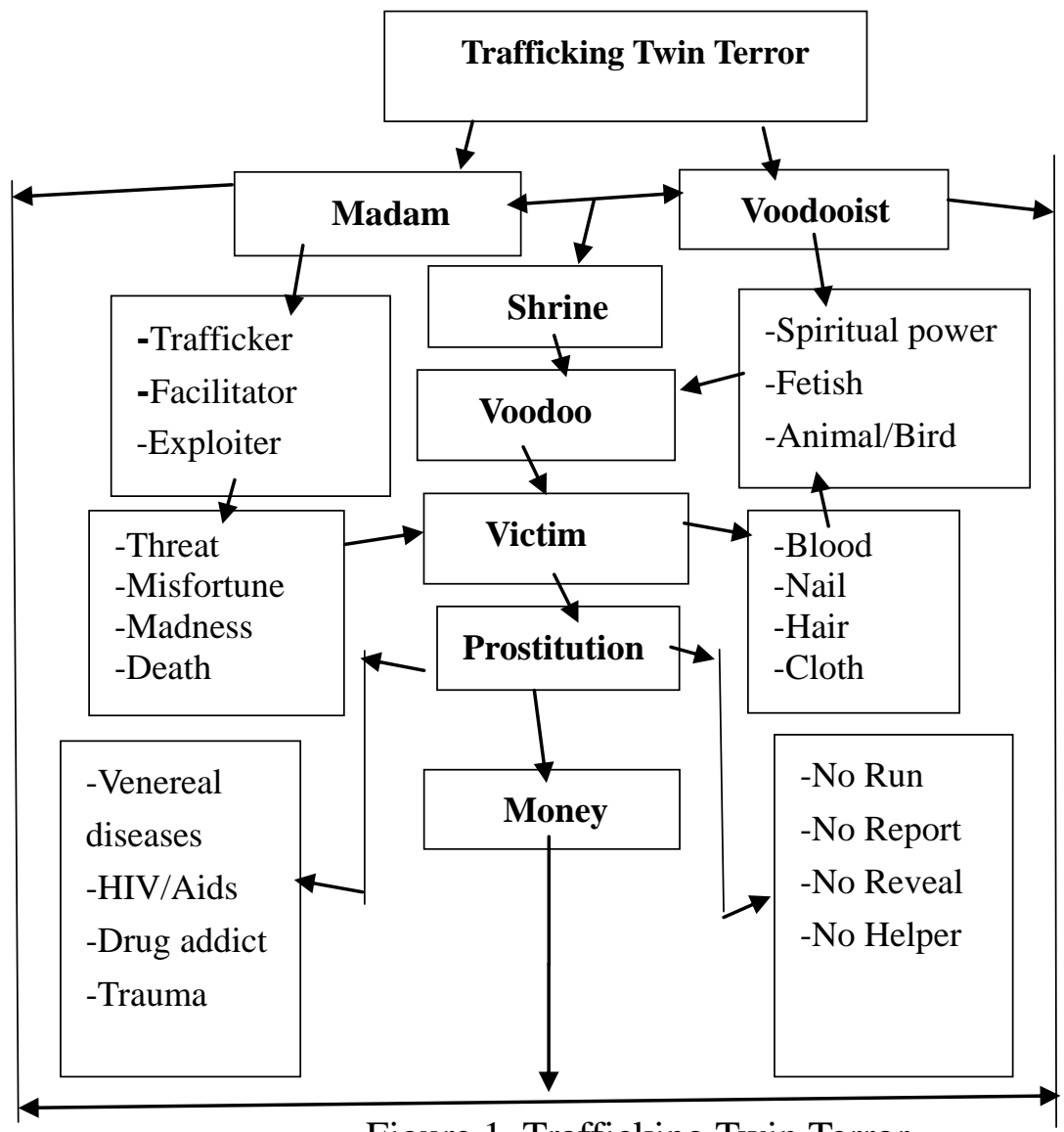

Figure 1. Trafficking Twin Terror

Source: Author(s)

\subsection{Madam and the Victim}

There are various reasons why it is difficult for the victims to reject the voodoo secrecy. Firstly, the victims frequently see the trafficker as a good citizen or helper and may much be willing to take the promise to console the trafficker of their faithfulness in return for an expected better job or a good life. Much of the time, it is for the trafficked women to concur effortlessly to paying the unbelievable debt incurred and in this manner obligations allocated to them by their traffickers. The traffickers, for the most part, depend on the illiteracy of the victims when calculating out the so-called debt (May, 2017). As a result, the victims are primarily, from villages or the rural areas and may have little or no idea of total money incurred (Williams \& Masika, 2002). To the said debt if converted into the Nigeria Naira in cash. Other victims who know about the comparability of the exchange rate are trick into trusting that it is easy to pay back the incurred expenses or money in a short period (probably not more than a year), an irrational presumption with regards to their plight (Ikeora, 2016). Thus, much of the time, the victims are bonded to the debts for a long time, and when they become unfit to pay the debt, they are retained in the prostitution industry until the point when their trafficker has no utilisation for the victims (Bales, 2000). 


\subsection{Madam a Leader that Breeds}

Many times victims see the repayment of debt as something that has a duration between two to three years unless they have committed something terrible which the madam does not like that will create an avenue to increase the period to serve as a punishment for what the victim has done. The length makes some victims comply with the contract, according to some victims the repayment years are not long, can withstand all difficulties and exploitation. It is the best and wisest choice for them (Mohammad, Joarder \& Paul, 2013). Thus, once the victim has served and reached the years stated, the contract is accomplished, the victim has gotten sort of freedom, but it could be extended depending on the decision of the madam. The prostituted victim now serves as a close associate, as she has complied with all the madam needed and has repaid all incurred expenses to the madam, followed her wishes. The victim at present serves as a supervisor to other victims in the prostitution trade for the madam and at the end gained experience and then transformed to a new madam through the said process (Carling, 2005). Consequently, Nigerian madams are not just leaders of traffickers but also a training ground for a cartel of criminals that breeds more madams, these aids, sustain and persist international prostitution.

\subsection{Voodoo Victimisation}

Juju as the vast majority in Western Africa call it, it shapes some portion of Africa's traditional belief, which is practised in various societies and towns. For example, the usage exists diversely over multiple groups and ethnic communities in Nigeria and is along these lines given several names, for instance, it is referred as the oath of secrecy by an interviewee that states:

The girls have taken the oath with the promise not to reveal the names of the traffickers, and this is the reason it is otherwise called oath of secrecy.

Thus, it is also, commonly known as juju as some interviewed participants call it. The juju is only one of the numerous names given to it_by different ethnic communities within Nigeria. Oath of secrecy, as described in multiple communities, supports the negative generalisation regularly credited to traditional belief reflecting deep fear in the spiritual powers. Abioje (2013) explains voodoo from the perspective of two distinct worlds, the invisible and the visible or the spiritual and the real voodoo. Voodoo is seen to take different forms and dimensions. The spirits and divinities are considered as intercessors between God and human beings through sacrifice and divination from the spiritualist words. Similarly, objects and gestures and that the voodoo priest has some spiritual power that brings assistance can bring money or riches, ensure successful passage and protect from harm (Dzokoto \& Glenn, 2005; Cherti, Jenny \& Peter, 2013; Ikeora, 2016).

In the same vein, voodoo is seen within the context of traditional belief and culture and how it is utilised as a method to perpetuate human trafficking for prostitution to Nigerian women. In this manner, according to Eghosa et al. (2005), religion in Nigeria is classified into three, namely; Muslim, Christian and traditional. Out of the three, the traditional is the less active politically. Furthermore, politicians and alike do regularly strive for help from traditional 
spiritualist. Consequently, according to Van \& Gijsbert, voodoo is a kind of witchcraft that existed alongside traditional belief, which at times not only politicians but some Christians and Muslims do believe in it in Nigeria. Hence, it is a varied form of West African religious tradition, whereby the priest uses voodoo in the shrine with supernatural power and influence to manoeuvre consequences in individuals live (2004). In western Africa, voodoo is widely used to seal business transaction or to find, punish or eliminate suspected thieve usually with a killer disease or deadly curse for the unlawful or criminal offence.

Accordingly, in Nigeria, clandestine trafficking network of criminals of human trafficking is mostly women controlling fellow women's life. The quest for riches paved the way for more victims; these arise from Nigeria madam, who are senior or former prostitutes. The madam is the facilitator and exploiter of the victims till all accrued debt are paid. It is the madam that pays for the recruitment, transportation, passport and other travel documents (Siegel \& De Blank, 2010; Usman, Ariffin \& Othman, 2017) and she arranges with the priest for the voodoo oath to be taking or administered. Thus, the voodoo could not be used, and victims held exploitatively without the madam's significant role as mentioned by an interviewee:

The voodoo is a means by the recruiter (madam) to ensure that the trafficking deal is sealed and irreversible.

\subsection{Voodoo: The Source, Parts, and Processes}

The voodoo is before the practice of present-day laws that guide and shape individuals, families and communities, in trading with each other, usually, a daily routine would, as a rule, seal their trading agreement with voodoo, just to guarantee that each side of the accord stayed faithful to their commitments. Destruction will go to the individual who tries to cheat on the other party. It is this tradition, the traffickers now take the advantage, by applying different dimension which was not meant for human trafficking purposes. Thus, the voodooist under the instruction of madam use to impart fear to the victims, and because the victims likewise trust that the juju will work, they are hesitant to do anything in spite of that they concurred with the madam. Accordingly, studies on Nigeria shows more than eighty percent of the trafficked women in Europe had passed through the shrine for juju oath, which has been administered to the victims (Mojeed, 2008; Jenny, 2011; Etchingham, 2015). Thus, the oath is meant for victims to swear by the spirit to pay incurred expenses as dictated and decided by the madam. Also, never to reveal traffickers' identity and if at all come across or meet law enforcer deny being a victim of prostitution (Jenny, 2011; Maria, Guia \& May, 2016). Victims usually cannot runway due to the fear that the juju will haunt them. Also, they are worried about the consequences of breaking the oath they had taken and remain under the command and control of the trafficker (Marcel \& Beatri, 2017).

Accessible information from some interview respondents demonstrates that there is no uniform technique for performing the juju. However, the procedure regularly includes the utilisation of herbs or plants, which might be blended with other not known substances including blood from various creatures or from birds and animals to be mixed and the young women will be required or forced to drink. Victim's part of the body like nail, hair, and blood may as well be taken from the young women and held by the juju priest. These, as indicated 
by most of the respondents said it is done to subject the young women to fear because it is frequently trusted that voodoo is more powerful when it includes the body fluid particular blood of the woman involved. In this manner, a respondent categorically and emotionally shows concern for the plight of the victims as cited:

The shrine man slaughter lives chicken, and the trafficked women were commanded to eat the uncooked raw heart. Victims pubic hair and fingernails were trimmed, and retained, to impart fear and signify how they could be reached whenever they try to resist.

In this way, similar but different from the interviewee is Mojeed's assertion that young women are typically taken to the priest shrine and made to take the oath of mystery when victims reach the destination nation, they are usually forced to another voodoo taking (2008). In various cases, juju fills in as a sign concerning whether or not the madam will proceed with the trafficking procedure; especially, when consideration is that to fill in as a means to shield traffickers from arrest. For the most part, the voodoo taking takes place in the sourcing nations, with a regular ritual carried out on the victims. As indicated by most respondents and confirmed with the written documents, the rituals regularly require attire of the victims, their fingernails, pubic hair, blood, and so forth. Some of these victims additionally specified the utilisation of their clothing in the voodoo rite. Discussing how the juju is administered is an interviewee statement that:

Traffickers and the juju priest usually take some parts of the young women body organs like nail, pubic hair, particularly blood, which are then used to prepare the voodoo and compel the victims. We have specific mental cases among the returned victims. One cannot state whether the oath has worked or not.

Understanding differently by a respondent commented:

Young women trafficked into prostitution are attached to the oath of secrecy, the aim is specifically for a victim not to run or change mind.

In this way, the whole situation of the ritual creates an atmosphere of fear, combined with the rituals which can be somewhat violent and threatening. Sometimes, a portion of the victim's body taken at the shrine for the voodoo, are held by the traffickers, relatively signify possession, control and command the victim, with the goal that regardless of where she is, the victim is not far from being annihilated (Ikeora, 2016). Thus, usually fleeing is not seen by most victims as a secure alternative. Where victimisation is carried out via physical abuse or violence, this kind of clandestine viciousness frequently has to do with more of psychological damage than the physical. The victim may regularly be ignored in the process of identification as trafficking person. Many of times it includes the slaughter of animals or chickens, and the victims will be asked to eat raw meat without being processed.

\subsection{Voodoo: Persistency, Privacy and Profitability}

One of the needed thing to do before the madam acquire the migration documents as a significant aspect of the prostitution procedure, victims experience the voodoo oath in a selected shrine, obliged to pay or settle back the so-called excessive debt and obey with the 
dictates of the madam under all situations. The money that accrued from the victim's passage is in some rear cases concurred before embarking on the journey, but mostly, it is after the rituals are performed and can run into thousands of dollars as profit for the traffickers (Akee, Basu, Bedi \& Chau, 2014). In consequence, the use of threat, beaten, rape and violence have demonstrated most profitable for traffickers of African victims (Farley, Cotton, Lynne, Zumbeck, Spiwak, Reyes, Alvarez, \& Sezgin, 2004; May, 2017), primarily because of the belief in supernatural and ancestral spirits held by various African societies. This voodoo taking fills in as a contract between the madam and the victim with the sole aim to have loyalty, mystery, secrecy and repayment of the cost of her journey and additionally, other benefits and profit costs acquired simultaneously, all exclusively dictated by the madam (Ikeora, 2016; Usman et al., 2017).

\subsection{Voodoo and Madam: Dangers and Dilemmas of the Victim}

The consequences of this oath taking are not just destructive to the trafficked women, yet it is likewise an obstacle to the anti-trafficking measures, particularly for law enforcers and policy implementers. The fear and worry are that the voodoo creates a considerable lot of these victims regularly serve as an obstruction to investigate, apprehend and prosecute traffickers, an interviewee is worried and disturbed as discussed:

The voodoo is a great set back to successful arraignment and prosecution of trafficker since the woman (victim) who has been star witness is unwilling to reveal her ordeal as result of the fear of juju.

While now and again it likewise serves as an impediment to the protective measures put in place for the victims. The investigation used to be upset since victims are terrified to give reliable information to enforcement officers because of the voodoo oath coerced on them. Therefore, the victims may have proven to continuously be conflicting with the vital information that they decide to give, regularly that ends in the culprits (traffickers) getting away from being convicted. The absence of evidence as a result of victims trusting the oath of secrecy. As indicated by an interviewee:

Traffickers likewise utilise the juju to shield the girls from uncovering and revealing the traffickers' name, and that is the reason some victims prefer not to talk.

Furthermore, the consequences being of discontinuing the agreement are frequently thought to be misfortunes, sickness, hardship or death for the trafficked woman and her loved ones (Toyin $\&$ Niyi, 2007). Trafficked women who have experienced this voodoo taking trust that if they reveal or they uncover their experience and provide proof about their madam, they will face and encounter numerous tragedies. Such calamities may involve being killed, encounter psychological illness and disaster or torment to her family through sickness or death, amongst various sorts of causes, which the victim has concurred during the voodoo oath. Agazue (2013) additionally stated that trafficked women who have passed the voodoo become 'mentally enslaved.' Hence, a belief held by the victims, they may frequently do not tell the truth about their prostitution experiences with regards to the juju oath to protect themselves. This phobia might be additionally escalated by the terrified victims that they usually feel when trafficked 
victims are assessed by law enforcers. As indicated by one respondent:

They usually use to hide their traffickers; they do not want to tell us; victims are typically brainwashed; charm is being used on them so that they don't name the traffickers.

These issues regularly emerge from components, for instance, inquiry and a lack of understanding cultural values, which frequently limits implementers from seeking the correct queries to produce the required rapport. Few victims tend to show elements of mental or memory loss. They often show that they cannot recall their encounters in detail, endeavouring to stifle the thinking of their contacts or having a tendency to live trying to claim ignorance of their sexual experiences. Besides, they often feel disgraced and ashamed. Some accuse themselves of influencing such oath, this is on account of the oath of secrecy are by and large seen as abominable, even by some African people who now turn themselves into 'mainstream religions' like Christianity, amongst others. Moreover, voodoo priests are regularly recognised as devil worshipers by the majority of Nigerian individuals who are Islamic and Christian faithful's (Agazue, 2013).

Also, in several cases, victims that have experienced similar kind of trafficking, do have less trust in enforcement officers, who sometimes do conclude that victims are with limited information. While some victims usually capitalised on such flimsy claims of voodoo to avoid enforcement officers or to seek asylum. Victims who could not give necessary evidence as a result of voodoo are the more substantial number, which means an overall effect on protection and assistance, halting the implementation of Naptip trafficking policies. It showed there is dire need to understand voodoo as a significant source that persisted and sustained international prostitution in Nigeria and it prevents prosecution, unable to convict traffickers as well as a setback to the protection of victims. Thus, without the facilitator of the madam as the main trafficker, mastermind, and initiator of taking victims to the priest, the voodoo will not be in place or used on victims.

\section{Conclusion and Recommendations}

The study looks into the trafficking twin terror, that is the madam and voodoo priest understand their modus operandi, the connivance to perpetuate the dastardly acts against the victims. Breaking into the criminal network through engaging direct host community leaders is an immediate, required and short-term solutions to the scourge of international prostitution. Significant findings on human trafficking for international prostitution primarily focus on poverty, illiteracy, and unemployment. These are long-term solvable to the menace; improvement is not immediate. Nigeria government needs to rethink the issue, as crucial stakeholders remain at the federal level while significant exploitation continues and persist at the local or grassroots level. Thus, there is a dire need for the grassroots leaders to be active in the fight against prostitution scourge. Federal government Naptip agency remains saddled with activities of human trafficking and government at the national level maintained the decision making.

Conversely, the third tier of government at the grassroots level is well-known as the closest to the people. These individuals involve the village heads, ward heads, district heads, and 
community leaders. But virtually remain out of the fight against traffickers. They are the ones who know the terrain, know almost everyone within their jurisdiction, master the community geography and history very well, understand what is happening around, know better than anyone else, they should be active leaders and part of the trafficking decision making as well. Attach with or working hand in hand is the religious institution, they have proven many times, and victims feel comfortable and much better because they know, they have the remedy to the voodoo. The evidence was from this study, a respondent that used similar religious knowledge also with wisdom and experiences. In the same vein, the nature and kind of trafficking activities to be cured, eliminate the voodoo and victims to gain back confidence, this is the task of religious leaders, their profession that they are best known and capable of doing, the religious institution should be part of the solution.

The central government needs to change the game, as we are not moving in the actual and right direction. It is almost impossible for a federal government civil servants despite having the fundamental training to win the fight against traffickers in a village he knows very little about their way of life. In the same way, most Naptip staff acknowledged being referred to and recognised by the populace as a federal government agency. Thus, it is common to see Naptip staff from South East in the Northwestern state of Nigeria or the vice versa, virtually with little knowledge of the people, the culture, the communities and the like and expect her/him to work at best. Communities themselves have to own this as a project, it is a well-known fact, that deception by an outsider is almost impossible without an insider. Similarly, we must not allow our well-established community structures that existed for ages, well known regarding community policing, neighbour to neighbour sharing of food, cloth, gift, circulating information, and coming together to address common problems. These and more are what the then Nigerian communities are best known for, but they have mostly faded. The governments must not allow these to continue; it should be revived, as traffickers usually take advantages of loose, less concern and fragmented societies.

Lastly, traffickers, many times are hidden, but their heinous activities of recruiting the victims and the shrine places are not hidden but available within communities. Some community members do know what is going own, but they are afraid to voice out due to fear of reprisal, primarily as a result of the break down of the community cohesion that existed. Presently, people are looking at all these human traffickers' dealings and happenings. All we need is the commitment from the governments (federal, state and local) to get these crucial actors on board, set the pace rightly, the time for mere rhetoric is long gone, international prostitution continues to take different forms and dimension, we have to do it correctly at this crucial time.

\section{References}

Abioje, P. O. (2013). Divine Revelation in Yoruba Traditional Religion and in Christianity. Journal of Humanities and Social Science, 6(4), 42-49. https://doi.org/10.9790/0837-0644249

Adepoju, A. (2005). Review of research and data on human trafficking in sub-Saharan Africa. International Migration, 43(2), 75-98. https://doi.org/10.1111/j.0020-7985.2005.00313.x

Adesina, O. S. (2014). Modern-day slavery: poverty and child trafficking in Nigeria. African 
Identities, 12(2), 165-179. https://doi.org/10.1080/14725843.2014.881278

Agazue, C. (2013). The Role of a Culture of Superstition in the Proliferation of Religio-Commercial Pastors in Nigeria. (1st Ed.). Indiana: Author House.

Agbu, O. (2003). Corruption and human trafficking: The Nigerian case. West Africa Review, $4(1), 1-13$.

Akee, R., Basu, A, K., Bedi, A., \& Chau, N, H. (2014). Transnational trafficking, law enforcement, and victim protection: A middleman trafficker's perspective. The Journal of Law and Economics, 57(2), 349-386. https://doi.org/10.1086/675404

Arsovska, \& Jana, B. D. (2013). Globalizing the Western Balkans: Transnational Crime, Fundamental Islam and Unholy Alliances. Études caribéennes, 22. https://doi.org/10.4000/etudescaribeennes.5871

Bales, K. (2000). Expendable people: Slavery in the age of globalisation. Journal of International Affairs, 53(2), 461-484.

Bell, S. (2011). Trafficked girls controlled by Juju magic rituals. [Online] Available: http://www.bbc.com/news/uk-14044205 (July 7, 2011)

Campana, P. (2015). The structure of human trafficking: Lifting the bonnet on a Nigerian transnational network. British Journal of Criminology, 56(1), 68-86. https://doi.org/10.1093/bjc/azv027

Carling, J. (2005). Gender dimensions of international migration. Global migration perspectives, 35, 1-26.

Cherti, M., Jenny, P., \& Peter, G. (2013). Beyond borders: Human trafficking from Nigeria to the UK. London: Institute for Public Policy Research.

Dzokoto, V. A., \& Glenn, A. (2005). Understanding Genital-Shrinking Epidemics in West Africa: Koro, Juju, or Mass Psychogenic Illness? Culture, Medicine and Psychiatry, 29(1), 53-78. https://doi.org/10.1007/s11013-005-4623-8

Eghosa, E. O., \& Rotimi, T. S. (2005). A History of Identities, Violence, and Stability in Nigeria. (1st Ed.). United Kingdom: University of Oxford.

Etchingham, J. (2015). Rise in the evil trade of trafficking people from Nigeria to the UK. [Online] Available: http://www.itv.com/news/2015-10-15/ (October 15, 2015)

Evelyn, N, U., \& Chukwuka, O. N. (2017). Human trafficking: Commercial sexual exploitation and forced domestic labour in African literature. Journal of Language and Cultural Education, 5(2), 1-15. https://doi.org/10.1515/jolace-2017-0023

Farley, M., Cotton, A., Lynne, J. M., Zumbeck, S., Spiwak, F., Reyes, M. E., .. \& \& Sezgin, U. (2004). Prostitution and Trafficking in Nine Countries, Journal of Trauma Practice, 2(3), 33-74. https://doi.org/10.1300/J189v02n03_03

Fiona, W. (2012). Converging variations in migrant care work in Europe. Journal of 
European Social Policy, 22(4), 363 - 376. https://doi.org/10.1177/0958928712449771

Golafshani, N. (2003). Understanding reliability and validity in qualitative research. The qualitative report, 8(4), 597-606.

Ikeora, M. (2016). The Role of African Traditional Religion and 'Juju' in Human Trafficking: Implications for Anti-trafficking. Journal of International Women's Studies, 17(1), 1-18.

International Organisation for Migration. (2016). Global Migration Trends Factsheet. [Online] Available: https://www.iom.int/news/iom-releases-global-migration-trends-2015-factsheet (April 19, 2016)

Jenny, K. (2011). The curse of 'juju' that drives sex slaves to Europe. [Online] Available: http://www.independent.co.uk/news/world/europe/the-curse-ofjuju-that-drives-sex-slaves-to europe 2264337.html (April 6, 2011)

Kleemans, E. R. (2007). Organized crime, transit crime, and racketeering. Crime and Justice, 35(1), 163-215. https://doi.org/10.1086/501509

Laczko, F. (2005). Data and research on human trafficking. International Migration, 43(1-2), 5-16. https://doi.org/10.1111/j.0020-7985.2005.00309.x

Mancuso, M. (2014). Not all madams have a central role: analysis of a Nigerian sex trafficking network. Trends in Organized Crime, 17(1-2), 66-88.

Marcel, W., \& Beatri, K. (2017). Exploring 'juju' and human trafficking: towards a demystified perspective and response, South African Review of Sociology, 48(2), 70-86. https://doi.org/10.1080/21528586.2016.1222913

Maria, J. G., \& May, L. S. (2016). How The Current 'Migration Crisis' Challenges European Criminologists. Newsletter of the European Society of Criminology. See also how-current-migration-crisis-challenges-european-criminologists. (2018). [Online] Available: http: //escnewsletter.org/newsletter/2016-1/

Masika, R., \& Williams, S. (2002). Gender, Trafficking and Slavery. (3rd Ed). Oxford: Oxfam Publisher. https://doi.org/10.3362/9780855987558

May, I. (2017). Bilateral Cooperation and Human Trafficking: Eradicating Modern Slavery between the United Kingdom and Nigeria. (1st Ed.). Switzerland: Springer International Publishing.

Mohammad, A. M., Joarder, \& Paul, W. M. (2013). A Theoretical Perspective on Human Trafficking and Migration-Debt Contracts, The Journal of Development Studies, 49(10), 1332-1343. https://doi.org/10.1080/00220388.2013.812195

Mojeed, M. (2008). Nigeria- Voodoo Aids Human Trafficking. [Online] Available: http://www.

lastradainternational.org/doc-center/2066/nigeria-voodoo-aids-human-trafficking.

Monzini, P. (2005). Sex traffic: prostitution, crime and exploitation. (1st Ed.). Bangkok: Zed 
Books.

National Agency for the Prohibition of Trafficking in Persons. (2017). 2017 First Quarter Report Modified. [Online] Available: https://www.naptip.gov.ng/ b?page_id=361 (May 26, 2017)

National Agency for The Protection of Trafficking in Persons and Other Related Matters (2017). Data on Human Trafficking. [Online] Available: https://www.naptip.gov.ng/?page_id=361 (May 26, 2017)

Oviasuyi, P. O., Ajagun, S. O., \& Lawrence, I. (2011). Fetish Oath Taking in Nigerian Politics and Administration: Bane of Development. Journal of Social Sciences, 27(3), 193-200. https://doi.org/10.1080/09718923.2011.11892920

Seo, Y. C., Axel, D., \& Eric, N. (2013). Does Legalized Prostitution Increase Human Trafficking? World Development, $\quad 41(1), \quad 67-82$. https://doi.org/10.1016/j.worlddev.2012.05.023

Siegel, D., \& De Blank, S. (2010). Women who traffic women: the role of women in human trafficking networks - Dutch cases. Global Crime, 11(4), 436-447. https://doi.org/10.1080/17440572.2010.519528

Toyin, F., \& Niyi, A. (2007). The Human Cost of African Migrations. England: Routledge.

United Nations Educational, Scientific and Cultural Organisation. (2018). Trafficking in Nigeria: Root Causes and Recommendations. [Online] Available: https:// unesdoc.unesco.org/images/0014/001478/147844e.pdf (January, 2018)

Usman, U. M., Ariffin, R. N. R., \& Othman, A. (2017). The Tripartite Trafficking. International Journal of Academic Research in Business and Social Sciences, 7(11), 1047-1061. http://dx.doi.org/10.6007/IJARBSS/v7-i11/3544

Van, L. G. (2004). Human trafficking in Europe: an economic perspective. Forced Labor, $31(9), 1-42$

Vanguard. (2018). NAPTIP engages Benin witch doctors to fight human trafficking. [Online] Available:

https://www.vanguardngr.com/2018/02/naptip-engages-benin-witch-doctors-fight-human-traf ficking/ (February 6, 2018)

Weitzer, R. (2015). Human trafficking and contemporary slavery. Annual review of sociology, 4l(1), 223-242. https://doi/abs/10.1146/annurev-soc-073014-112506

\section{Copyright Disclaimer}

Copyright for this article is retained by the author(s), with first publication rights granted to the journal.

This is an open-access article distributed under the terms and conditions of the Creative Commons Attribution license (http://creativecommons.org/licenses/by/4.0/). 